\title{
Suppression of mitochondrial respiration through recruitment of p160 myb binding protein to PGC-1 $\alpha$ : modulation by $\mathbf{p} 38$ MAPK
}

\author{
Melina Fan, ${ }^{1}$ James Rhee, ${ }^{1}$ Julie St-Pierre, ${ }^{1}$ Christoph Handschin, ${ }^{1}$ Pere Puigserver, ${ }^{2}$ Jiandie Lin, ${ }^{1}$ \\ Sibylle Jäeger, ${ }^{1}$ Hediye Erdjument-Bromage, ${ }^{3}$ Paul Tempst, ${ }^{3}$ and Bruce M. Spiegelman ${ }^{1,4}$ \\ ${ }^{1}$ Dana-Farber Cancer Institute and the Department of Cell Biology, Harvard Medical School, Boston, Massachusetts 02115, \\ USA; ${ }^{2}$ Johns Hopkins University Medical School, Baltimore, Maryland 21205, USA; ${ }^{3}$ Memorial Sloan-Kettering Cancer \\ Center, New York, New York 10021, USA
}

\begin{abstract}
The transcriptional coactivator PPAR gamma coactivator $1 \alpha$ (PGC-1 $\alpha$ ) is a key regulator of metabolic processes such as mitochondrial biogenesis and respiration in muscle and gluconeogenesis in liver. Reduced levels of PGC-1 $\alpha$ in humans have been associated with type II diabetes. PGC-1 $\alpha$ contains a negative regulatory domain that attenuates its transcriptional activity. This negative regulation is removed by phosphorylation of PGC-1 $\alpha$ by p38 MAPK, an important kinase downstream of cytokine signaling in muscle and $\beta$-adrenergic signaling in brown fat. We describe here the identification of p160 myb binding protein

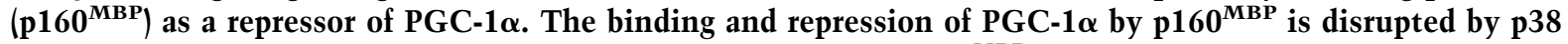
MAPK phosphorylation of PGC-1 $\alpha$. Adenoviral expression of $\mathbf{p}^{160}{ }^{\mathrm{MBP}}$ in myoblasts strongly reduces PGC-1 $\alpha$ 's ability to stimulate mitochondrial respiration and the expression of the genes of the electron transport system. This repression does not require removal of PGC-1 $\alpha$ from chromatin, suggesting that $\mathrm{p}^{160^{\mathrm{MBP}}}$ is or recruits a direct transcriptional suppressor. Overall, these data indicate that $\mathrm{p}^{160^{\mathrm{MBP}}}$ is a powerful negative regulator of PGC-1 $\alpha$ function and provide a molecular mechanism for the activation of PGC-1 $\alpha$ by p38 MAPK. The discovery of $\mathrm{p}^{160^{\mathrm{MBP}}}$ as a PGC-1 $\alpha$ regulator has important implications for the understanding of energy balance and diabetes.
\end{abstract}

[Keywords: PGC-1 $\alpha$, Mybbpla, mitochondria, repressor, p38 MAPK]

Supplemental material is available at http://www.genesdev.org.

Received September 15, 2003; revised version accepted December 11, 2003.

Most biological programs involving alterations in gene expression are regulated by changes in amounts or activities of DNA-binding transcription factors. However, recent evidence has shown that transcriptional coactivators can be important targets for physiologic regulation. PPAR gamma coactivator $1 \alpha($ PGC- $1 \alpha)$ has emerged as a key regulator of several aspects of mammalian energy metabolism. It was originally cloned as a binding partner for PPAR $\gamma$ (Puigserver et al. 1998), but interacts with and coactivates many transcription factors, such as nuclear respiratory factor 1 (NRF-1), myocyte-enhancing factor2C (MEF2C), and most members of the nuclear hormone receptor family (for review, see Puigserver and Spiegelman 2003).

PGC- $1 \alpha$ activates a broad program of adaptive thermo-

${ }^{4}$ Corresponding author.

E-MAIL bruce spiegelman@dfci.harvard.edu; FAX (617) 632-5363.

Article published online ahead of print. Article and publication date are at http://www.genesdev.org/cgi/doi/10.1101/gad.1152204. genesis characteristic of brown fat cells when expressed in white fat cells (Puigserver et al. 1998; Tiraby et al. 2003). This is characterized by mitochondrial biogenesis and an induction of the uncoupling protein 1, resulting in elevated respiration. PGC- $1 \alpha$ expression in muscle cells leads to elevated respiration and oxidative phosphorylation with increases in the expression of mitochondrial genes and the glucose transporter GLUT4 (Wu et al. 1999; Michael et al. 2001; St-Pierre et al. 2003). Importantly, expression of PGC-1 $\alpha$ in skeletal muscle in vivo via a transgene triggers the conversion of type IIb muscle fibers to type IIa and type I fibers, as evidenced by mitochondrial biogenesis and expression of myofibrillar proteins characteristic of slow-twitch muscle (Lin et al. 2002; Handschin et al. 2003). Most recently, decreases in skeletal muscle PGC- $1 \alpha$ have been associated with human type 2 diabetes and those at risk for the development of diabetes (Mootha et al. 2003; Patti et al. 2003). PGC- $1 \alpha$ is also associated with increased oxidative ca- 
pacity in heart. It is dramatically induced at birth when the heart has an increased requirement for mitochondrial respiration (Lehman et al. 2000). Moreover, PGC-1 $\alpha$ stimulates fatty acid oxidation in heart, which provides fuel for the respiratory chain (Vega et al. 2000).

PGC- $1 \alpha$ is induced in liver in response to fasting, and activates key genes of the fasting response, including the genes of the gluconeogenic pathway and $\beta$-oxidation of fatty acids (Herzig et al. 2001; Yoon et al. 2001; Puigserver et al. 2003; Rhee et al. 2003). This is of critical importance in diabetes because dysregulated gluconeogenesis is a key component of the hyperglycemia characteristic of both type I and type II diabetes.

In addition to these physiological changes in PGC- $1 \alpha$ gene expression, this coactivator is also controlled at the posttranslational level. PGC- $1 \alpha$ contains a negative regulatory region between amino acids 170 and 350, which reduces the function of the transcriptional activation domain located between amino acids 1 and 170 (Puigserver et al. 1999). This transcriptional suppression can be relieved via phosphorylation by p38 MAPK at residues Thr 262, Ser 265, and Thr 298 of murine PGC$1 \alpha$, all within the negative regulatory domain. These sites are likely to be physiologically relevant, as signaling upstream of p38 MAPK is activated during certain states of increased respiration and metabolic rates. For example, p38 MAPK is activated downstream of inflammatory cytokine stimulation in muscle (Knutti et al. 2001; Puigserver et al. 2001) and $\beta_{3}$-adrenergic stimulation in brown adipocytes (Cao et al. 2001), correlating with states of cachexia and cold exposure, respectively.

PGC- $1 \alpha$ that has been phosphorylated by p38 MAPK is both more stable and has augmented transcriptional activity relative to unphosphorylated protein (Puigserver et al. 2001). The increased stability of the p38 MAPK phosphorylated protein does not, however, fully explain the observed increase in transcriptional coactivation. A mutant PGC- $1 \alpha$ with alanine substitutions at the phosphorylation sites has similarly increased stability, but is much less active in stimulating mitochondrial gene expression and oxygen consumption (Puigserver et al. 2001). Hence, the p38 MAPK-mediated phosphorylation is able to activate PGC- $1 \alpha$ function through at least two distinct mechanisms.

We describe here the identification of p160 myb binding protein (Mybbpla, herein called p160 ${ }^{\mathrm{MBP}}$ ) as a repressor of PGC- $1 \alpha$ that interacts with PGC- $1 \alpha^{\prime}$ s negative regulatory domain and reduces its transcriptional and biological activities. Moreover, p160 ${ }^{\mathrm{MBP}}$ binding is disrupted by $\mathrm{p} 38$ MAPK phosphorylation of PGC- $1 \alpha$, providing a mechanistic explanation for the positive regulation of this coactivator by p38 MAPK.

\section{Results}

p160 ${ }^{M B P}$ interacts with the regulatory domain of PGC-1 $\alpha$ and inhibits its transcriptional activity

To investigate the mechanism of regulation of PGC- $1 \alpha$ through its suppressor domain, we performed affinity chromatography using a GST-fusion protein containing amino acids $200-400$ of PGC- $1 \alpha$ and nuclear extracts from $\mathrm{C} 2 \mathrm{C} 12$ myoblasts. The parent GST protein and GST fused to amino acids 1-200 of PGC-1 $\alpha$ [GSTPGC1(1-200)] were used as controls. After binding and washing, the GST proteins and associated proteins were eluted with free glutathione, separated by SDS-PAGE, and silver stained. A unique constellation of proteins interacted with GST-PGC1(200-400) compared with GST-PGC1(1-200) or the control GST protein (Fig. 1A).

Proteins binding to GST-PGC1(200-400) were excised from SDS-PAGE gels and identified by a combination of peptide mass fingerprinting using matrix-assisted laser desorption/ionization-time-of-flight (MALDI-TOF) mass spectrometry (MS), and mass spectrometric sequencing using NanoES triple-quadruple MS/MS (Winkler et al. 2002). Several proteins containing hnRNP or splicing motifs were among those found to interact with GSTPGC1(200-400), highlighting PGC-1 $\alpha$ 's role in RNA processing (Supplemental Table 1). We also purified two components of the anaphase-promoting complex, tsg24 and cdc16. cdc16 is indicated in Figure $1 \mathrm{~A}$ and will be examined in later experiments. Our attention is focused on another interacting protein, $\mathrm{p} 160^{\mathrm{MBP}}$, because it was previously identified as a negative regulator of a transcription factor, c-myb (Tavner et al. 1998). To confirm this identification, we used antibodies against $\mathrm{p} 160^{\mathrm{MBP}}$ in Western blots of the proteins purified with the GST fusions. As shown in Figure 1B, p160 $\mathrm{MBP}$ indeed interacts strongly with GST-PGC1(200-400) compared with GST alone.

$\mathrm{p} 160^{\mathrm{MBP}}$ has been previously shown to be expressed ubiquitously and is posttranslationally processed in some cells to create an N-terminal fragment of $67 \mathrm{kD}$, p $67^{\mathrm{MBP}}$ (Tavner et al. 1998). Previous work showed that p $160^{\mathrm{MBP}}$ did not alter c-myb's transcriptional activity in transfection assays, whereas $\mathrm{p} 67^{\mathrm{MBP}}$ reduced c-myb transcription by $80 \%$. We cloned mouse $\mathrm{p} 160^{\mathrm{MBP}}$ and $\mathrm{p} 67^{\mathrm{MBP}}$ separately into mammalian expression vectors and tested them on PGC-1 $\alpha$.

HIB1B brown fat cells were cotransfected with a fusion protein connecting the yeast Gal4 DNA binding domain (Gal4-DBD) with full-length PGC-1 $\alpha$, along with an appropriate Gal4-UAS-luciferase reporter, and $\mathrm{p} 160^{\mathrm{MBP}}$ or $\mathrm{p} 67^{\mathrm{MBP}}$. Luciferase assays were conducted $24 \mathrm{~h}$ later and revealed that both $\mathrm{p} 160^{\mathrm{MBP}}$ and $\mathrm{p} 67^{\mathrm{MBP}}$ dramatically repressed Gal4-PGC1 $\alpha$ transcriptional activity, by $80 \%$ and $96 \%$, respectively (Fig. 1C). In contrast, a version of PGC- $1 \alpha$ that has lost its negative regulatory region, Gal4-PGC1 $(\Delta 170-350)$, was not significantly affected by either $\mathrm{p} 160^{\mathrm{MBP}}$ or $\mathrm{p} 67^{\mathrm{MBP}}$ expression. These data demonstrate that both $\mathrm{p} 160^{\mathrm{MBP}}$ and $\mathrm{p} 67^{\mathrm{MBP}}$ have inhibitory effects on PGC- $1 \alpha$ activity and that these effects are dependent on the regulatory region of PGC- $1 \alpha$ to which these factors bind.

Wild-type PGC- $1 \alpha$ does not bind to DNA directly, but rather functions as a coactivator of transcription factors. To study the effects of $\mathrm{p} 160^{\mathrm{MBP}}$ and $\mathrm{p} 67^{\mathrm{MBP}}$ on PGC- $1 \alpha$ in a more native context, we cotransfected vectors expressing these proteins with PGC- $1 \alpha$ and one of its transcription factor targets, PPAR $\gamma$. A multimerized PPAR $\gamma$ 
Fan et al.

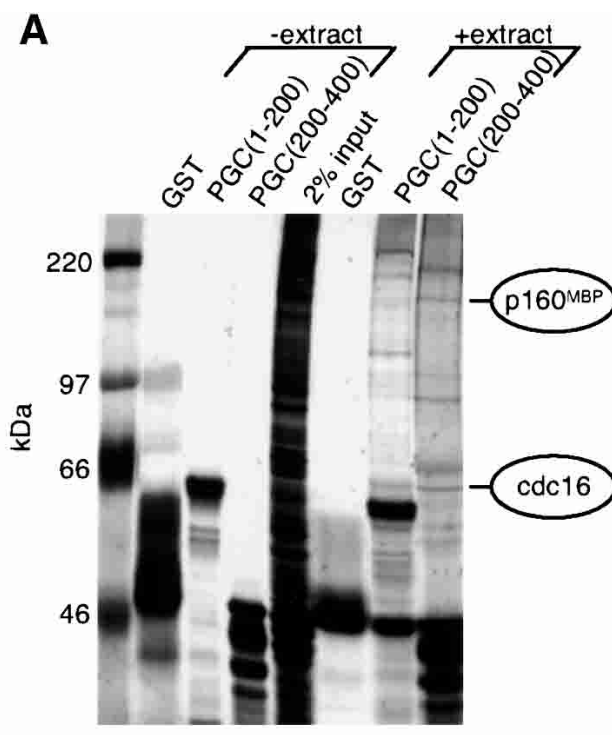

silver stain

B

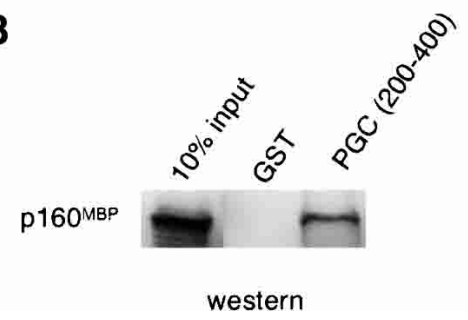

C

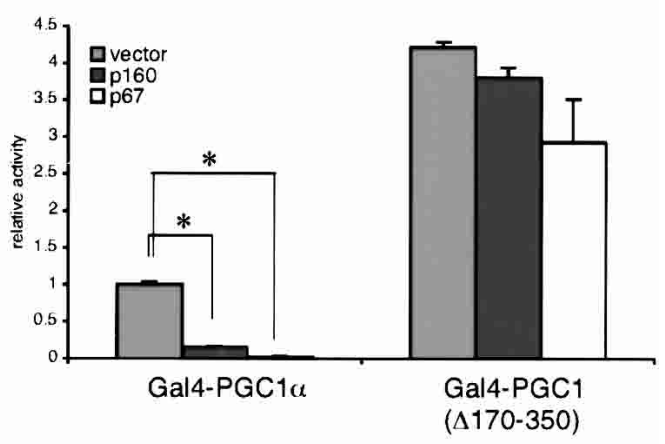

D

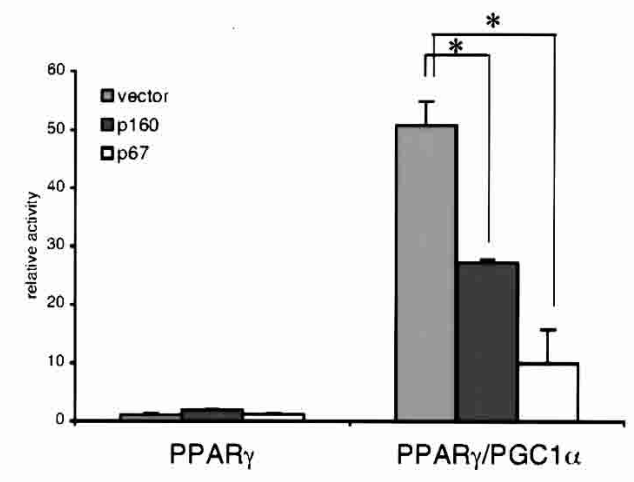

Figure 1. p160 $\mathrm{MBP}$ interacts with GST-PGC1(200-400) and suppresses PGC-1 $\alpha$-mediated transcription. C2C12 muscle cell nuclear extracts were incubated with bacterially expressed GST fusion proteins on glutathione sepharose beads. PGC(1-200) is GST-PGC1 $\alpha(1-$ $200)$ and PGC $(200-400)$ is GST-PGC1 $\alpha(200-400)$. The interacting proteins were run on an SDS-PAGE gel and $(A)$ silver stained or $(B)$ Western blotted with antibodies against $\mathrm{p} 160^{\mathrm{MBP}}$. $(C) \mathrm{p} 160^{\mathrm{MBP}}$ or $\mathrm{p} 67^{\mathrm{MBP}}$ was cotransfected with Gal4-PGC1 $\alpha$ or Gal4-PGC1( $\Delta 170-$ $350)$ and a UAS-luciferase reporter in HIB1B cells. Luciferase activity was measured after $24 \mathrm{~h}$. (Asterisks) $P<0.001$, paired $t$-test. $(D)$ PPAR $\gamma$ and RXR $\alpha$ with or without PGC- $1 \alpha$ were cotransfected with a DR-1-luciferase reporter into HIB1B cells. p160 ${ }^{\mathrm{MBP}}$ or $\mathrm{p67} 7^{\mathrm{MBP}}$ were also added and luciferase levels were measured after $24 \mathrm{~h}$. All luciferase assays were normalized for transfection efficiencies using $\beta$-galactosidase. (Asterisks) $P<0.001$, paired $t$-test.

response element (DR-1) linked to a luciferase reporter gene was used to measure transcriptional activity. Although $\mathrm{p} 160^{\mathrm{MBP}}$ and $\mathrm{p} 67^{\mathrm{MBP}}$ had minimal effects on PPAR $\gamma$ alone, they both significantly diminished PGC$1 \alpha^{\prime}$ s coactivation of PPAR $\gamma$ (Fig. 1D). These results indicate that both $\mathrm{p} 160^{\mathrm{MBP}}$ and $\mathrm{p} 67^{\mathrm{MBP}}$ are able to repress PGC- $1 \alpha^{\prime}$ s trancriptional coactivation in transient transfection.

\section{Both $N$ - and C-terminal domains of $p 160^{M B P}$ interact} with PGC-1 $\alpha$

A series of deletions of $\mathrm{p} 160^{\mathrm{MBP}}$ were constructed to determine which regions of this protein are responsible for the interaction with PGC-1 $\alpha$. Given the repressive effects of $\mathrm{p} 67^{\mathrm{MBP}}$ on PGC-1 $\alpha$, it was expected that the $\mathrm{N}$ terminus of this molecule would interact with PGC- $1 \alpha$. Therefore, in addition to the $\mathrm{p} 67^{\mathrm{MBP}}$ protein, this $\mathrm{N}$-terminal region was also divided into three portions, amino acids 1-200, 200-400, and 400-580. An expression vector for the remainder of $\mathrm{p} 160^{\mathrm{MBP}}$, which is not encompassed in $\mathrm{p} 67^{\mathrm{MBP}}$, was also generated and is termed p160C (Fig. 2A).

When in vitro translated portions of $\mathrm{p} 160^{\mathrm{MBP}}$ were incubated with GST-PGC1(200-400), it was clear that PGC- $1 \alpha$ interacted with $\mathrm{p} 160^{\mathrm{MBP}}$ through both the Nterminal and C-terminal halves of $160^{\mathrm{MBP}}$ (Fig. 2B). Within the subdomains of the $\mathrm{N}$ terminus of $\mathrm{p} 160^{\mathrm{MBP}}$, the only segment that showed detectable binding to PGC-1 $\alpha$ was p160(200-400) (Fig. 2B). It is interesting that $\mathrm{p} 160^{\mathrm{MBP}}$ is predicted to contain two leucine zipper motifs, one at aa 307 to 335 , and another at 900 to 928 (Tavner et al. 1998). Both of these lie within segments that bind to PGC- $1 \alpha$, and it is possible that they play a role in this interaction. In fact, $\mathrm{p} 160^{\mathrm{MBP}}$ interacts with leucine-rich regions of c-myb and c-jun, and mutations of specific leucines on PGC- $1 \alpha$ disrupt $\mathrm{p} 160^{\mathrm{MBP}}$ binding (discussed in Fig. 3). Neither p160C nor any of 
A

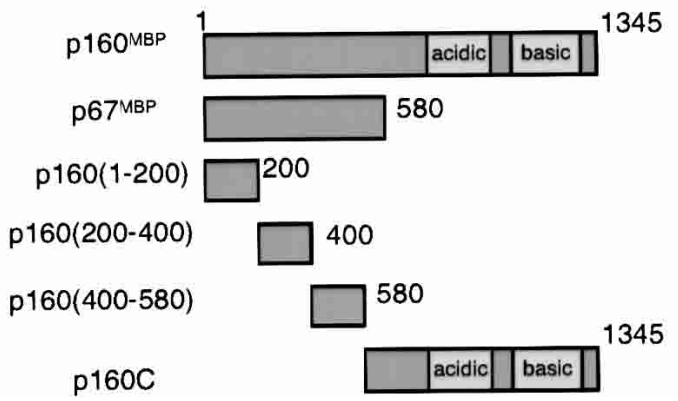

B

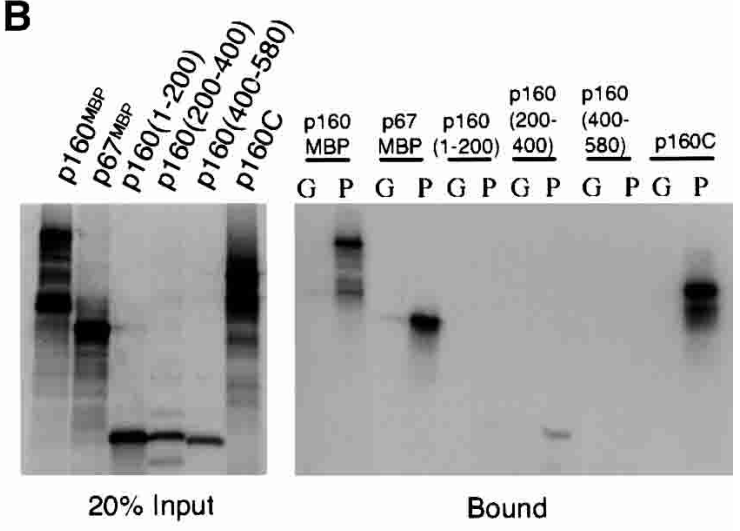

Figure 2. PGC- $1 \alpha$ binds to amino acids $200-400$ and to the $C$ terminus of $\mathrm{p} 160^{\mathrm{MBP}}$. (A) Summary of p160 ${ }^{\mathrm{MBP}}$ deletion constructs used in this experiment. (B) GST, labeled G, or GST-PGC1(200-400), labeled P, were incubated with in vitro translated ${ }^{35}$ S-p160 ${ }^{\mathrm{MBP}}$ deletions for $1 \mathrm{~h}$. Interacting proteins were run on an SDS-PAGE gel and visualized by autoradiography.

the smaller fragments of $\mathrm{p} 67^{\mathrm{MBP}}$ were able to suppress the transcriptional activity of Gal4-PGC1 $\alpha$ (data not shown), suggesting that some of the key functional domains of $\mathrm{p} 160^{\mathrm{MBP}}$ lie outside of the PGC-1 $\alpha$ interaction region.

\section{p38 MAPK phosphorylation of PGC-1 $\alpha$ blocks} its interaction with $160^{M B P}$

p38 MAPK directly phosphorylates amino acids Thr 262, Ser 265, and Thr 298 in the repressor region of PGC-1 $\alpha$ and leads to a protein that is both more stable and more transcriptionally active (Knutti et al. 2001; Puigserver et al. 2001). The p38 MAPK sites are highly conserved across species and are downstream of both cytokine and $\beta$-adrenergic signaling cascades (Tracey et al. 1987; Cao et al. 2001). We therefore investigated the possibility that phosphorylation of PGC- $1 \alpha$ could interfere with p $160^{\mathrm{MBP}}$ binding to the negative regulatory region of PGC-1 $\alpha$. p38 MAPK was used to phosphorylate GSTPGC1(200-400) in vitro under conditions in which the vast majority of the protein becomes phosphorylated and has reduced mobility in SDS-PAGE [GST-PGC(200-400)P] (Fig. 3A). Identical protein that was incubated with p38 MAPK in the absence of ATP was used as a control [GST-PGC1(200-400)]. As seen in Figure 3A, GST-PGC1 (200-400)-P bound much less p160 ${ }^{\mathrm{MBP}}$ from C2C12 nuclear extracts than the mock phosphorylated GST-PGC1 (200-400) protein (Fig. 3A). In contrast, cdc16 binds equally well to PGC-1 $\alpha$ with or without phosphorylation. These data indicate that p38 MAPK phosphorylation of PGC- $1 \alpha$ specifically inhibits its binding to $\mathrm{p} 160^{\mathrm{MBP}}$.

We also asked whether phosphorylation of PGC- $1 \alpha$ disrupts its interaction with $\mathrm{p} 160^{\mathrm{MBP}}$ in cells. Flagtagged PGC- $1 \alpha$ (f:PGC $1 \alpha)$ and myc-tagged $\mathrm{p} 160^{\mathrm{MBP}}$ were cotransfected into BOSC cells and treated with the cytokines interleukin- $1 \alpha$ (IL-1 $\alpha)$, interleukin- $1 \beta$ (IL-1 $\beta$ ), and tumor necrosis factor $\alpha(\mathrm{TNF} \alpha)$ to induce p38 MAPK-mediated phosphorylation of PGC- $1 \alpha$ (Puigserver et al. 2001). PGC-1 $\alpha$ was then immunoprecipitated and the complex was run on SDS-PAGE and analyzed by Western blotting. Despite the fact that cytokines increased the amount of PGC- $1 \alpha$ protein, as expected, less myc-tagged $\mathrm{p} 160^{\mathrm{MBP}}$ was immunoprecipitated with PGC- $1 \alpha$ when cells were treated with cytokines (Fig. 3B).

We next examined the effects of p38 MAPK on PGC$1 \alpha$ and $\mathrm{p} 160^{\mathrm{MBP}}$ by measuring transcriptional activity in cells. MKK6, the upstream activator of p38 MAPK, was used to stimulate phosphorylation of Gal4-PGC1 $\alpha$ in C2C12 myoblasts. As shown previously (Knutti et al. 2001; Puigserver et al. 2001) and in Figure 3C, MKK6 activates the transcriptional activity of Gal4-PGC1 $\alpha$. However, whereas p $160^{\mathrm{MBP}}$ and $\mathrm{p} 67^{\mathrm{MBP}}$ suppress the transcriptional activity of Gal4-PGC1 $\alpha$, MKK6 completely relieves this suppression.

To confirm that the p38 MAPK modulation of the PGC- $1 \alpha$ and $\mathrm{p} 160^{\mathrm{MBP}}$ interaction is a consequence of the direct action of p38 MAPK on PGC- $1 \alpha$, we created a mutant of PGC- $1 \alpha$ that replaces the phosphorylated residues with aspartic acids (PGC1-3D). The aspartate residues are used to mimic a phosphorylated version of PGC-1 $\alpha$. There may also be additional effects of MKK6 on other components of the PGC-1 $\alpha$ pathway, but the PGC1-3D mutant allows us to test the portion of the MKK6 activation that directly targets PGC- $1 \alpha$ protein itself. As shown in Figure 3D, the mutated Flag-tagged PGC-1 $\alpha$ (f:PGC1-3D) coimmunoprecipitated significantly less myc-tagged $\mathrm{p} 160^{\mathrm{MBP}}$ when cotransfected in BOSC cells. This mutant is more transcriptionally active than wild-type PGC- $1 \alpha$, coactivating PPAR $\gamma$ by 30 -fold as compared with wild-type PGC-1 $\alpha$ 's 20 -fold on a DR-1 luciferase reporter (Fig. 3E). When $\mathrm{p} 160^{\mathrm{MBP}}$ and $\mathrm{p} 67^{\mathrm{MBP}}$ were coexpressed with PGC-1 $\alpha$ or PGC1-3D, PGC1-3D was resistant to repression by $\mathrm{p} 160^{\mathrm{MBP}}$ and $\mathrm{p} 67^{\mathrm{MBP}}$. Together, these data indicate that the positive effects of $\mathrm{p} 38$ MAPK on PGC- $1 \alpha$ activity occur largely via direct modulation of PGC- $1 \alpha$ to diminish $\mathrm{p} 160^{\mathrm{MBP}}$ binding.

It has previously been shown that a titratable repressor interacts with PGC- $1 \alpha$ and is dependent on the leucine motifs LXXLL (L2), beginning at amino acid 147, and 
Fan et al.
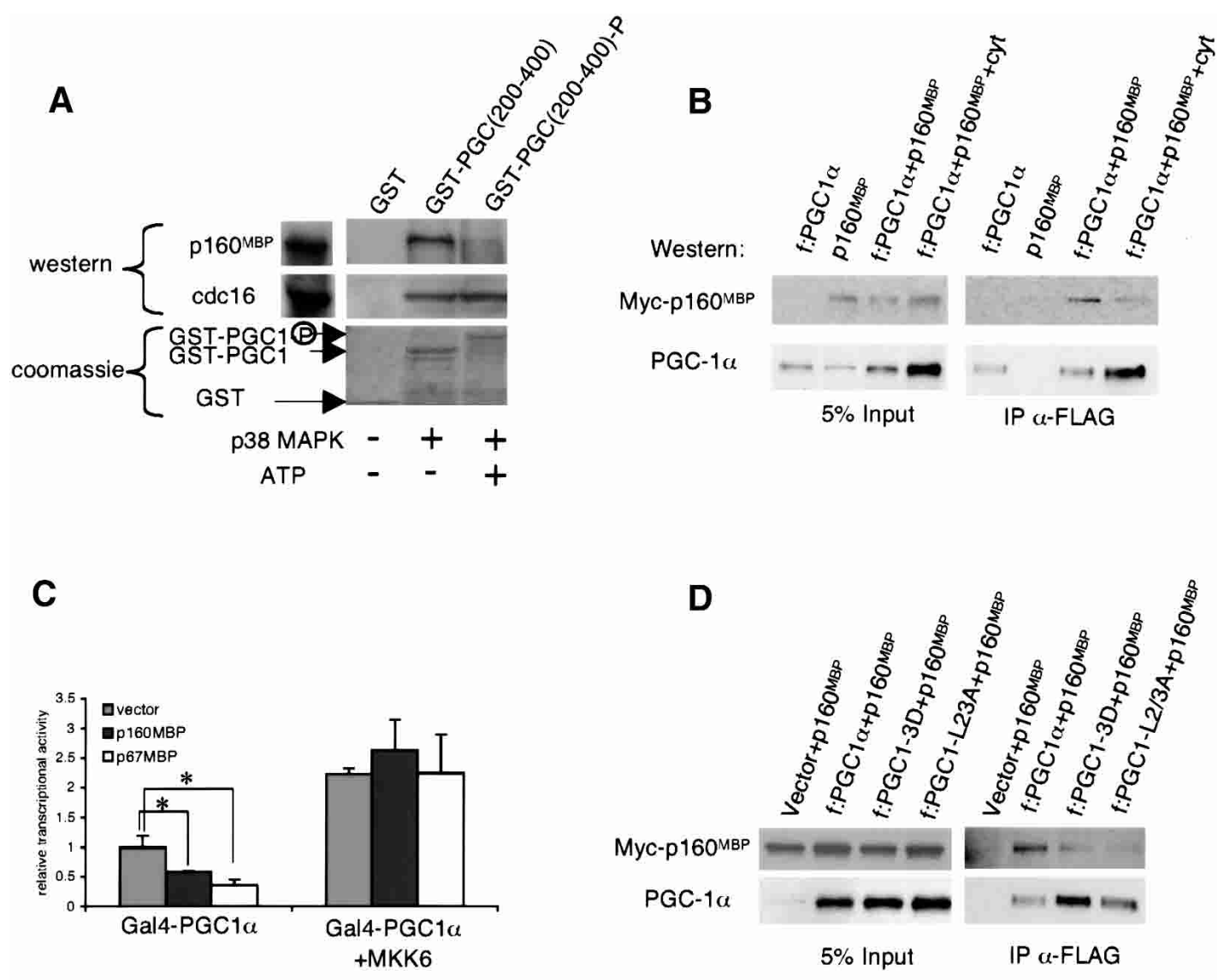

E

$\mathbf{F}$
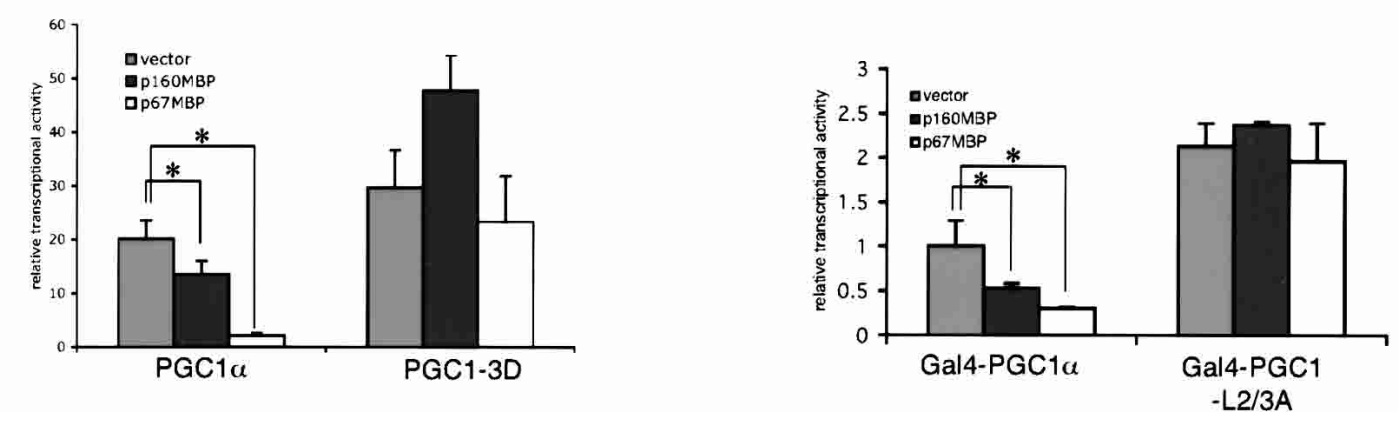

Figure 3. $\mathrm{p} 160^{\mathrm{MBP}} \mathrm{s}$ interaction with PGC- $1 \alpha$ is modulated by $\mathrm{p} 38$ MAPK phosphorylation. $(A)$ GST-PGC1(200-400) was phosphorylated in vitro by activated p38 MAPK in the presence of ATP [GST-PGC1(200-400)-P] or mock phosphorylated in the absence of ATP [GST-PGC1(200-400)]. The GST proteins were then incubated with C2C12 nuclear extracts and interacting proteins were visualized by Western blot by using antibodies against $\mathrm{p} 160^{\mathrm{MBP}}$ or against cdc16 (Santa Cruz Biotechnology). (B) Flag-tagged PGC-1 $\alpha$ (f:PGC1 $\alpha$ ) was cotransfected with myc-tagged $160^{\mathrm{MBP}}\left(\mathrm{myc}-\mathrm{p} 160^{\mathrm{MBP}}\right)$ in BOSC cells and after $24 \mathrm{~h}$ treated with the cytokines IL- $1 \alpha$, IL- $1 \beta$, and TNF $\alpha$ overnight in DMEM + 0.5\% BSA. Whole-cell extracts were immunoprecipitated with M2 anti-Flag antibodies (Sigma) and Western blots were conducted with antibodies against myc or PGC-1 $\alpha$ (Santa Cruz Biotechnology). The left panel is a Western blot of $5 \%$ of the whole-cell extract before immunoprecipitation and the right panel is a Western blot of the immunoprecipitated proteins. (C) Gal4-PGC1 $\alpha$ was cotransfected in C2C12 cells with a UAS-luciferase reporter and a vector expressing MKK6, the upstream activator of p38 MAPK. Medium was changed to DMEM $+0.5 \%$ BSA after $24 \mathrm{~h}$, and luciferase activity was measured after $48 \mathrm{~h}$. (Asterisks) $P<0.05$, paired $t$-test. $(D)$ Myc-p160 ${ }^{\mathrm{MBP}}$ was cotransfected with f:PGC1 $\alpha$, f:PGC1 $\alpha$ with the phosphorylation sites mutated to aspartic acid (f:PGC1-3D), or f:PGC1 $\alpha$ with selected leucines at L2 and L3 mutated to alanine (f:PGC1-L2/3A). Extracts were immunoprecipitated with anti-Flag antibodies as described earlier. $(E)$ PGC-1 $\alpha$ or PGC1-3D were cotransfected with PPAR $\gamma$, RXR, and DR-1 luciferase reporter in HIB1B cells. Cells were harvested after $24 \mathrm{~h}$ and fold activation over PPAR $\gamma$ was graphed. (Asterisks) $P<0.05$, paired $t$-test. $(F)$ Gal4-PGC1 or Gal4-PGC1-L2/3A were cotransfected with a UAS-TATA-luciferase reporter in C2C12 cells, and luciferase activity was measured after $24 \mathrm{~h}$. (Asterisks) $P<0.05$, paired $t$-test. 
LLXXL (L3), starting at amino acid 210 (Knutti et al. 2001). Mutation of the leucine motifs to AXXLL and AAXXL, respectively, relieves the suppressive effects of the regulatory domain of PGC- $1 \alpha$. Figure 3D shows that a PGC- $1 \alpha$ containing mutations in the leucine motifs (f:PGC1-L2/3A) was unable to coimmunoprecipitate $\mathrm{p} 160^{\mathrm{MBP}} \cdot \mathrm{p} 160^{\mathrm{MBP}}$ and $\mathrm{p} 67^{\mathrm{MBP}}$, when transfected into $\mathrm{C} 2 \mathrm{C} 12$ cells, failed to suppress the transcriptional activity of a version of Gal4-PGC1 $\alpha$ containing the leucine mutations (Gal4-PGC1-L2/3A; Fig. 3F). Because mutation of either the L2 or L3 motif alone was not sufficient to completely abolish p160 ${ }^{\mathrm{MBP}}$ repression, we conclude that both the L2 and L3 motifs contribute to $\mathrm{p} 160^{\mathrm{MBP}} \mathrm{s}$ interaction with full-length PGC- $1 \alpha$ (data not shown). Despite the fact that the leucine motifs are 50 amino acids away from the phosphorylation sites, Gal4-PGC1L2/3A no longer undergoes phosphorylation-induced in- creases in transcription (Knutti et al. 2001). This is consistent with the data indicating that $\mathrm{p} 160^{\mathrm{MBP}}$ binding is regulated by PGC- $1 \alpha$ phosphorylation. If $\mathrm{p} 160^{\mathrm{MBP}}$ cannot bind to the Gal4-PGC1-L2/3A mutant, phosphorylation of this mutant would not be expected to result in increased activity via $\mathrm{p} 160^{\mathrm{MBP}}$ dissociation.

\section{Adenoviral expression of $p 160^{M B P}$ decreases $P G C-1 \alpha$-mediated respiration and mitochondrial gene expression}

Adenoviral vectors for $\mathrm{p} 160^{\mathrm{MBP}}$ and $\mathrm{p} 67^{\mathrm{MBP}}$ were generated to investigate their activity on physiological functions of PGC-1 $\alpha$. These viruses were used in conjunction with adenoviral-PGC1 $\alpha$ to infect $\mathrm{C} 2 \mathrm{C} 12$ muscle cells, which were then harvested after $48 \mathrm{~h}$ for respiration studies and RNA analyses. As shown in Figure 4, A and
A

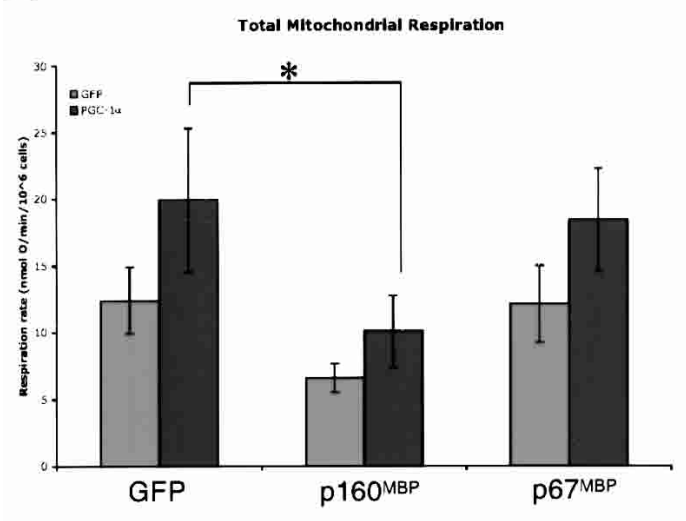

C

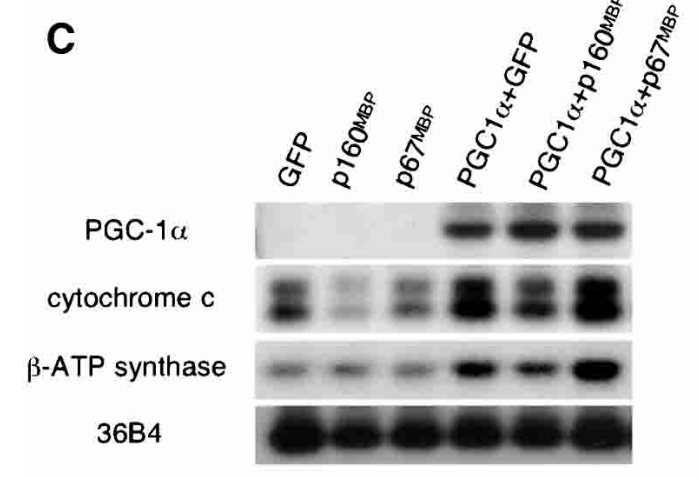

B

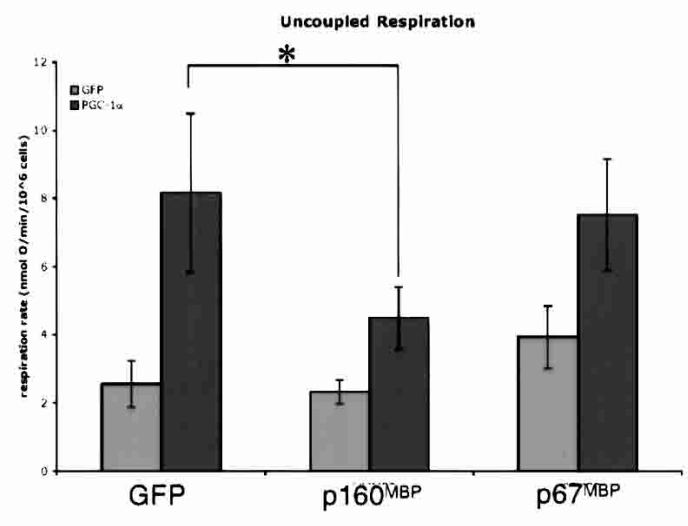

D cytochrome c

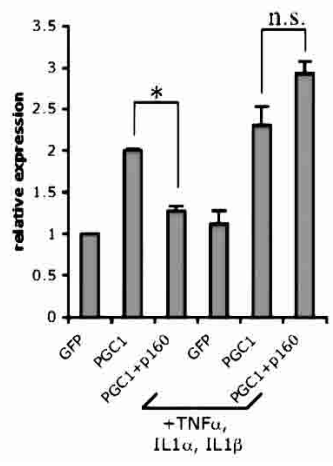

$\beta$-ATP synthase

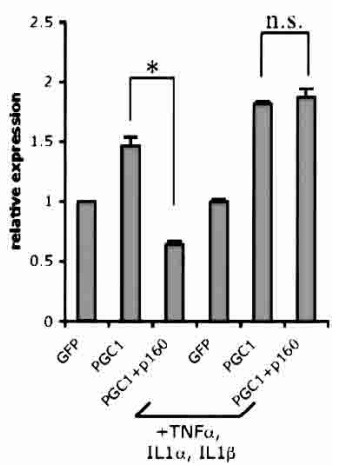

Figure 4. $\mathrm{p} 160^{\mathrm{MBP}}$ suppresses PGC-1 $\alpha^{\prime}$ s biological effects in muscle cells. C2C12 myoblasts were coinfected with adenoviral PGC1 $\alpha$ and $\mathrm{p} 160^{\mathrm{MBP}}$. Adenoviral GFP was used in the control infections. After $48 \mathrm{~h},(A)$ total mitochondrial oxygen consumption and $(B)$ uncoupled respiration were measured in live muscle cells. Uncoupled respiration represents the fraction of mitochondrial respiration that is not coupled to ATP production and was attained through addition of the ATP-synthase inhibitor oligomycin. (Asterisks) $P<0.05$, repeat ANOVA, a posteriori Tukey test. $(C)$ Same as in $A$ and $B$, except instead of using cells for oxygen consumption assays, RNA was harvested and Northern blots were performed. $(D)$ C2C12 myoblasts were coinfected with adenoviral PGC1 $\alpha$ and p160 ${ }^{\mathrm{MBP}}$ in serum-free media. TNF $\alpha$, IL- $1 \alpha$, and IL- $1 \beta$ were added at the time of infection and cells were harvested after $24 \mathrm{~h}$. Real-time PCR was used to quantitate RNA levels. (Asterisks) $P<0.05$, paired $t$-test; (n.s.) not statistically significant, paired $t$-test. 
C, and has been shown previously, expression of PGC- $1 \alpha$ causes a rise in total mitochondrial oxygen consumption and the expression of genes of the mitochondrial electron transport system. Coexpression of $\mathrm{p} 160^{\mathrm{MBP}}$ reversed the effects of PGC-1 $\alpha$, causing a complete elimination of PGC-1 $\alpha$-driven mitochondrial oxygen consumption. This was accompanied by a reduction in the target genes cytochrome $\mathrm{c}$ and $\beta$-ATP synthase. There was also a slight decrease in the respiration of cells infected with adenoviral GFP and $\mathrm{p} 160^{\mathrm{MBP}}$, although this did not reach statistical significance. The small change in basal respiration may be due to the repression of the endogenous PGC- $1 \alpha$ in C2C12 myoblasts, or to an as yet undescribed activity of $\mathrm{p} 160^{\mathrm{MBP}}$ on respiration. Interestingly, $\mathrm{p} 67^{\mathrm{MBP}}$ did not alter oxygen consumption or PGC-1 $\alpha$ target gene expression in these experiments despite the data shown earlier indicating that $\mathrm{p} 67^{\mathrm{MBP}}$ is a more potent repressor of PGC- $1 \alpha$ in transient transfections. Western blots confirmed that both adenoviral p $160^{\mathrm{MBP}}$ and $\mathrm{p} 67^{\mathrm{MBP}}$ were expressed efficiently in these experiments, with p $67^{\mathrm{MBP}}$ expressed at slightly higher levels than $\mathrm{p} 160^{\mathrm{MBP}}$ (data not shown). Thus, it appears that full-length $\mathrm{p} 160^{\mathrm{MBP}}$ protein is necessary for suppressive function on endogenous PGC$1 \alpha$ target genes. This suggests that the $\mathrm{C}$ terminus of p $160^{\mathrm{MBP}}$ is important for repression on chromatinized, endogenous DNA, but it is not required on plasmid DNA.

We also measured the effect of $\mathrm{p} 160^{\mathrm{MBP}}$ on the uncoupled fraction of mitochondrial respiration by adding the drug oligomycin to block ATP synthase. PGC- $1 \alpha$ has been shown to have more potent effects on induction of mitochondrial leak than on induction of total oxygen consumption (St-Pierre et al. 2003). Figure 4B shows that uncoupled respiration is robustly induced by PGC- $1 \alpha$, and $\mathrm{p} 160^{\mathrm{MBP}}$ represses the PGC-1 $\alpha$-driven proton leak by $>60 \%$. p $160^{\mathrm{MBP}}$ 's repression of proton leak is specific for PGC-1 $\alpha$-infected cells as compared with cells infected with GFP. Together, these experiments indicate a role for $\mathrm{p} 160^{\mathrm{MBP}}$ in the suppression of PGC- $1 \alpha^{\prime}$ s regulation of mitochondrial respiration and gene expression.

We next added cytokines and tested whether $\mathrm{p} 160^{\mathrm{MBP}}$ would still be able to suppress PGC- $1 \alpha$ induction of target genes. Because cytokines lead to phosphorylation of PGC- $1 \alpha, \mathrm{p} 160^{\mathrm{MBP}}$ should no longer suppress PGC- $1 \alpha$ activity. C2C12 myotubes were infected with adenoviral PGC- $1 \alpha$ and $\mathrm{p} 160^{\mathrm{MBP}}$, with or without cytokines, in the absence of serum. Because of the toxicity associated with the cytokines and serum starvation, RNA was harvested after only $24 \mathrm{~h}$, and subjected to real-time PCR. Although $\mathrm{p} 160^{\mathrm{MBP}}$ suppressed cytochrome $\mathrm{c}$ and $\beta \mathrm{ATP}$ synthase expression in the absence of cytokines, addition of a cocktail of TNF $\alpha$, IL- $1 \alpha$, and IL- $1 \beta$ completely eliminated this suppression (Fig. 4D). This further supports a model in which $\mathrm{p} 160^{\mathrm{MBP}}$ 's action on PGC- $1 \alpha$ is inhibited by PGC-1 $\alpha$ phosphorylation.

\section{p160 ${ }^{M B P}$ has intrinsic transcriptional repressive activity}

There are several possible mechanisms, not mutually exclusive, for how $\mathrm{p} 160^{\mathrm{MBP}}$ might mediate repression of
PGC-1 $\alpha$ function. Our primary hypotheses were based on previous work indicating that cytokines altered both the protein stability and transcriptional activity of PGC$1 \alpha$. We studied this in two different cell types relevant to the biology of PGC-1 $\alpha$ : brown fat and muscle. We first looked at PGC-1 $\alpha$ protein levels in the brown fat HIB1B cells cotransfected with $\mathrm{p} 160^{\mathrm{MBP}} \cdot \mathrm{p} 160^{\mathrm{MBP}}$ caused a dramatic decrease in the amount of full-length PGC- $1 \alpha$ protein (Fig. 5A), and a similar decrease was seen with a truncated version of PGC- $1 \alpha$ containing only the first 400 amino acids. In contrast, a mutant of PGC- $1 \alpha$ containing only the first 180 amino acids, which does not bind to p160 ${ }^{\mathrm{MBP}}$, was not affected. The triple aspartic acid mutant, PGC1-3D, which also does not bind significantly to $\mathrm{p} 160^{\mathrm{MBP}}$, was similarly unchanged. Although we were unable to ascertain effects of $\mathrm{p} 160^{\mathrm{MBP}}$ on PGC$1 \alpha$ RNA because of the low transfection, the fact that all of these versions of PGC- $1 \alpha$ are expressed from the same vector strongly suggests that the differences seen in protein level represent a change in protein stability rather than a change in transcript expression from the CMV promoter.

We also investigated $\mathrm{p} 160^{\mathrm{MBP}}$-mediated PGC- $1 \alpha$ repression in $\mathrm{C} 2 \mathrm{C} 12$ muscle cells, the cell type in which the oxygen consumption assays and target gene studies were conducted. In contrast to the data shown earlier with HIB1B, we did not see a clear effect of $\mathrm{p} 160^{\mathrm{MBP}}$ on PGC- $1 \alpha$ protein amount in C2C12 (Fig. 5B). To investigate whether repression occurs through the direct action of $\mathrm{p} 160^{\mathrm{MBP}}$ on the promoter of PGC- $1 \alpha$ target genes, we used a well-characterized PGC- $1 \alpha$ target gene in muscle cells, myoglobin. PGC- $1 \alpha$ coactivates MEF2C on a welldefined site on the myoglobin promoter (diagram in Fig. 5C; Yan et al. 2001; Handschin et al. 2003).

C2C12 myotubes were infected with MEF2C, PGC- $1 \alpha$, and $\mathrm{p} 160^{\mathrm{MBP}}$. RNA analyses and Western blots were conducted in parallel to determine the amount of PGC- $1 \alpha$ RNA and protein in the presence of $\mathrm{p} 160^{\mathrm{MBP}}$. Real-time PCR analysis revealed that $\mathrm{p} 160^{\mathrm{MBP}}$ represses PGC- $1 \alpha-$ induced activation of myoglobin by almost $60 \%$ without altering the amount of PGC- $1 \alpha$ mRNA or protein (Fig. $5 \mathrm{~B})$. We therefore conclude that, in $\mathrm{C} 2 \mathrm{C} 12$ myotubes, $\mathrm{p} 160^{\mathrm{MBP}}$ is working through a mechanism other than alteration of PGC-1 $\alpha$ protein stability.

We next used chromatin immunoprecipitations to ask whether PGC- $1 \alpha$ remained bound to the myoglobin promoter under the influence of $\mathrm{p} 160^{\mathrm{MBP}}$. C2C12 myotubes were infected with MEF2C, Flag-tagged PGC-1 $\alpha$, and $\mathrm{p} 160^{\mathrm{MBP}}$. Protein and DNA were cross-linked and chromatin was sheared before immunoprecipitation using anti-Flag antibodies. PCR with primers flanking the MEF2C site of the myoglobin promoter was then used to detect if PGC-1 $\alpha$ was bound to the myoglobin promoter. Figure $5 \mathrm{D}$ shows that PGC- $1 \alpha$ is recruited to the myoglobin MEF2C site, but that $\mathrm{p} 160^{\mathrm{MBP}}$ does not alter this recruitment. Thus, PGC- $1 \alpha$ remains bound to the myoglobin promoter even in the presence of $\mathrm{p} 160^{\mathrm{MBP}} \mathrm{s}$ suppression of this target gene. Western blots for PGC- $1 \alpha$ and MEF2C and a PCR of the MEF2C site from input DNA prior to the immunoprecipitation serve as con- 
A

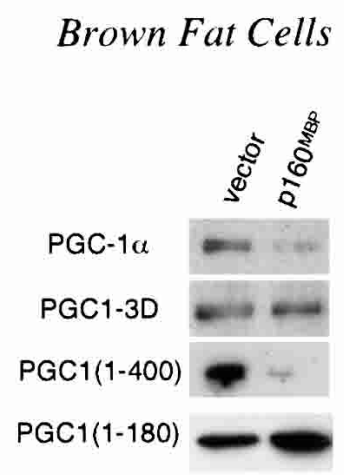

B

\section{Muscle Cells}

D

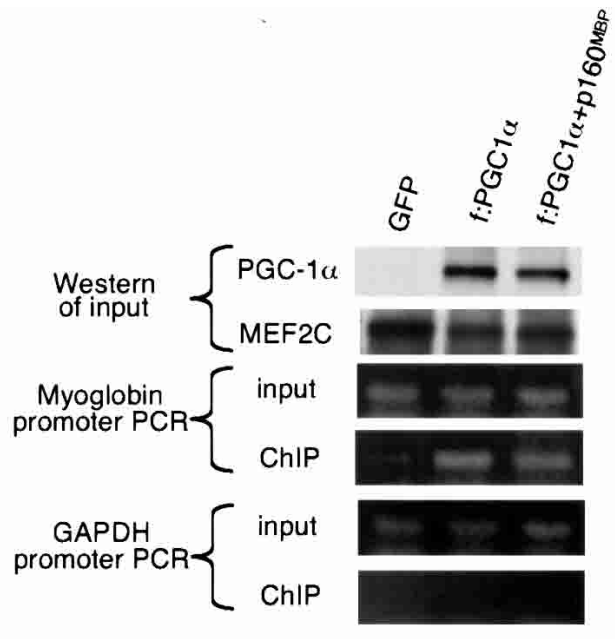

E

RNA

PGC-1 $1 \alpha$
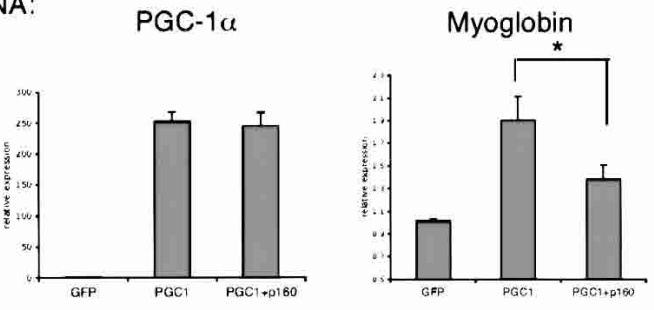

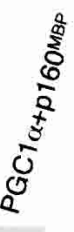

PGC-1 $\alpha$ actin

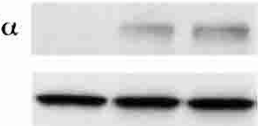

Protein

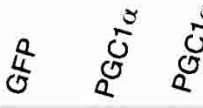

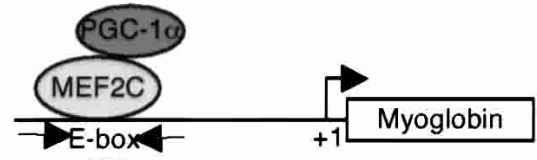

$-130$

PCR primers for ChIP

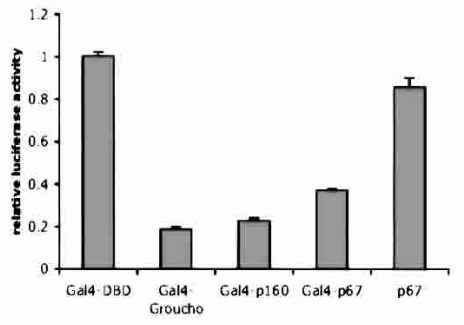

F

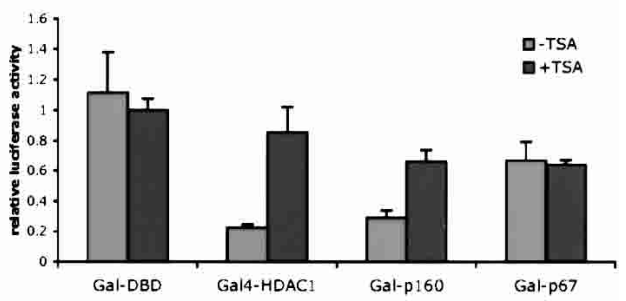

Figure 5. $\mathrm{p} 160^{\mathrm{MBP}}$ does not alter PGC-1 $\alpha$ protein level or recruitment to DNA. (A) HIB1B brown fat cells were cotransfected with $\mathrm{p} 160^{\mathrm{MBP}}$ and various versions of PGC-1 $\alpha$. Cell extracts were Western blotted for PGC-1 $\alpha .(B)$ C2C12 myotubes were coinfected with adenoviral MEF2C, PGC-1 $\alpha$, and $160^{\mathrm{MBP}}$ and harvested for RNA and protein. RNA was subjected to real-time PCR analysis to determine the amounts of PGC-1 $\alpha$ and myoglobin transcripts. Protein was blotted with antibodies against PGC-1 $\alpha$ or the loading control actin. (Asterisk) $P<0.05$, paired $t$-test. $(C)$ Diagram of PGC-1 $\alpha$ interaction with MEF2C on the myoglobin promoter; sites for PCR primers for chromatin immunoprecipitation assays are indicated. $(D) \mathrm{C} 2 \mathrm{C} 12$ myotubes were coinfected with adenoviral MEF2C, Flag-tagged PGC-1 $\alpha$, and $\mathrm{p} 160^{\mathrm{MBP}}$. Chromatin immunoprecipitations were carried out using M2 anti-Flag antibodies. The input and immunoprecipitated DNA were used as templates for PCR with primers flanking the MEF2C site at -130 on the myoglobin promoter. Primers amplifying a region of the GAPDH gene were used as a negative control. $(E)$ Gal4 fusion protein constructs were transfected into $\mathrm{C} 2 \mathrm{C} 12$ myoblasts with a UAS-tk-luciferase reporter. The cells were harvested after $24 \mathrm{~h}$ and luciferase activity was measured. $(F)$ Similar to $E$, except $100 \mu \mathrm{g} / \mathrm{mL}$ trichostatin A (TSA) was added after $12 \mathrm{~h}$. 
trols. A region of the GAPDH gene was also used for PCR from the input and immunoprecipitated DNA, and confirmed that PGC-1 $\alpha$ specifically immunoprecipitated the myoglobin promoter, but not GAPDH.

Because p160 ${ }^{\mathrm{MBP}}$ does not displace PGC-1 $\alpha$ from the promoter of a target gene, we hypothesized that $\mathrm{p} 160^{\mathrm{MBP}}$ itself might contain inherent transcriptional repressive activity. Hence, the mere recruitment of $160^{\mathrm{MBP}}$ to PGC-1 $\alpha$ would serve to lower transcription. To study p $160^{\mathrm{MBP}}$ s intrinsic repressive activity, we fused p160 16 BP to Gal4's DNA binding domain and tested it on a UAS-tk-luciferase reporter. The tk promoter has significant basal transcriptional activity and therefore is useful for testing transcriptional repressors. We used Gal4-Groucho, a known transcriptional repressor, as a positive control for this assay. Gal4-Groucho expression results in an $80 \%$ reduction in transcription. Strikingly, Gal4-p160 ${ }^{\mathrm{MBP}}$ and Gal4-p67 ${ }^{\mathrm{MBP}}$ were capable of repressing the UAS-tk-luciferase reporter to nearly the same extent as Gal4-Groucho (Fig. 5E). Expression of a version of $\mathrm{p} 67^{\mathrm{MBP}}$ that was not fused to the Gal4 DNA binding domain had no effect, confirming that recruitment to the promoter is essential for this repression. These data are consistent with a model in which $\mathrm{p} 160^{\mathrm{MBP}}$ binds to PGC- $1 \alpha$ on the DNA and directly represses its transcriptional activity.

A common mechanism of transcriptional repression is through deacetylation of histones. We used the histone deacetylase inhibitor trichostatin A (TSA) to investigate the possibility that $\mathrm{p} 160^{\mathrm{MBP}}$ possesses intrinsic histone deacetylase activity or recruits a histone deacetylase. In a transient transfection in $\mathrm{C} 2 \mathrm{C} 12$ myoblasts, Gal4$\mathrm{p} 160^{\mathrm{MBP}}$ s repressive activities were diminished by the addition of TSA (Fig. 5F). This indicates that at least part of the suppressive activity of $\mathrm{p} 160^{\mathrm{MBP}}$ is dependent on histone deacetylases. It is notable that TSA had no effect on Gal-p $67^{\mathrm{MBP}}$, highlighting the functional difference in the properties of these two molecules. Gal4-HDAC1 was used as a positive control. These studies provide insight into the mechanism of $\mathrm{p} 160^{\mathrm{MBP}}$ function, specifically suggesting the involvement of histone deacetylases.

\section{Discussion}

Although most biological regulation at the transcriptional level studied to date is attributed to alterations in amounts or activities of DNA-binding transcription factors, it is now clear that major control can be elicited through regulation of coactivator proteins. The first example of this was through the identification of OcaB, a B-cell selective coactivator of octomer binding proteins (Luo and Roeder 1995). Perhaps the most dramatic example of this, however, has been the coactivator PGC$1 \alpha$, which is a major regulator of metabolic functions in many tissues. PGC- $1 \alpha$ activates mitochondrial biogenesis and respiration in both brown fat and skeletal muscle, and is induced in the cold in both tissues (Puigserver et al. 1998; Wu et al. 1999). PGC-1 $\alpha$ is also expressed at high levels in skeletal muscle rich in type I fibers and can regulate muscle fiber type switching (Lin et al. 2002). PGC-1 $\alpha$ is induced in the liver on fasting, where it activates mitochondrial $\beta$-oxidation of fatty acids and gluconeogenesis (Herzig et al. 2001; Yoon et al. 2001).

Although PGC-1 $\alpha$ is greatly regulated at the transcriptional level, one mechanism has been described that indicates that important posttranslational control of this coactivator also occurs. p38 MAPK directly phosphorylates sites in the suppressor domain of PGC- $1 \alpha$, and greatly enhances its transcriptional activity (Puigserver et al. 2001). Although we originally described this p38 MAPK-mediated modification as a control point in the well-established role of cytokines in the activation of energy expenditure in vivo, recent data have shown that p38 MAPK is also activated downstream of cyclic AMP signaling in brown fat (Cao et al. 2001). Because cyclic AMP and CREB have been shown to be major players in the transcriptional control of PGC- $1 \alpha$ expression in many tissues, this raises the possibility that the p38 MAPK activation of PGC- $1 \alpha$ may be part of a coordinated program to increase the function of this coactivator at several levels simultaneously. Despite the data pointing to the importance of p38 MAPK modulation of PGC- $1 \alpha$ as a key control point, virtually nothing has been known about how these phosphorylation sites might exert their effects.

The data presented here describe $\mathrm{p} 160^{\mathrm{MBP}}$ as a repressor of PGC- $1 \alpha$ function. p $160^{\mathrm{MBP}}$ has been relatively uncharacterized to date. It was originally cloned as a repressor of c-myb, and its truncated form, p67 ${ }^{\mathrm{MBP}}$, was found to repress c-myb-mediated transcription (Tavner et al. 1998). p160 ${ }^{\mathrm{MBP}}$ also interacts with the transactivation domain of the aromatic hydrocarbon receptor. In this context, $\mathrm{p} 160^{\mathrm{MBP}}$ activates transcription in transient transfection (Jones et al. 2002). Thus far, the mechanism of $\mathrm{p} 160^{\mathrm{MBP}}$-mediated activation or repression has been unknown.

Several lines of evidence support the notion that modulation of PGC- $1 \alpha$ function by p38 MAPK is mediated, in significant measure, by $\mathrm{p} 160^{\mathrm{MBP}}$. First, p160 $160^{\mathrm{MBP}}$ was isolated in an unbiased biochemical purification as binding to the region of PGC- $1 \alpha$, aa $200-400$, which is associated with transcriptional suppression. Second, p38 MAPK-mediated phosphorylation of PGC- $1 \alpha$ in vitro greatly reduces the binding of $\mathrm{p} 160^{\mathrm{MBP}}$. Third, $\mathrm{p} 160^{\mathrm{MBP}}$ reduces the transcriptional activity and biological effects of PGC- $1 \alpha$, and in all cases, p38 MAPK-mediated phosphorylation reduces or completely blocks all of the effects of $\mathrm{p} 160^{\mathrm{MBP}}$. In addition, we have found that the binding of $\mathrm{p} 160^{\mathrm{MBP}}$ to PGC- $1 \alpha$ is reduced by mutation of leucines at motifs LXXLL (L2), which begins at amino acid 147, and LLXXL (L3), which begins at amino acid 210. These mutations have been previously suggested by Kralli and colleagues to block the binding of a putative titratable repressor of PGC-1 $\alpha$ (Knutti et al. 2001).

The discovery of molecular repressors of PGC- $1 \alpha$ is important because all of the experiments conducted with PGC-1 $\alpha$ to date have been gain-of-function experiments. A repressor could provide a valuable tool for studying the effects of decreasing PGC- $1 \alpha$ activity. A 
recent publication has suggested that the docking of the orphan nuclear receptor estrogen-related receptor $\alpha$ $(E R R \alpha)$ may depress PGC-1 $\alpha$ function through the same negative regulatory domain. However, the docking of $\mathrm{ERR} \alpha$ is not modulated by p38 MAPK-mediated phosphorylation, a modification known to reverse the function of the repressor domain (Ichida et al. 2002).

Our earlier work had indicated that the p38 MAPKmediated phosphorylation worked to suppress PGC- $1 \alpha$ function in at least two distinct ways: via changes in protein stability and via changes in transcriptional function that could not be explained simply through the changes in protein stability (Puigserver et al. 2001). This was shown most clearly in a mutant of PGC- $1 \alpha$ that had alanine substitutions (3A) at all three of the MAPK phosphorylation sites. This protein was stabilized to a comparable extent as the fully phosphorylated PGC- $1 \alpha$, but was far less active transcriptionally and biologically than the phosphorylated protein. The data presented here indicate that $\mathrm{p} 160^{\mathrm{MBP}}$ can dock on PGC- $1 \alpha$ and regulate its transcriptional activity and biological functions, notably in mitochondrial respiration and expression of genes of the electron transport system. This suppression seems to occur without modulation of PGC- $1 \alpha$ protein levels, at least in skeletal muscle, or removal of PGC- $1 \alpha$ from chromatin. As shown in chromatin immunoprecipitation assays (Fig. 5D), PGC- $1 \alpha$ remains bound to the myoglobin promoter at the crucial MEF2 binding site even under the negative regulation of $\mathrm{p} 160^{\mathrm{MBP}}$. This suggests a model whereby $\mathrm{p} 160^{\mathrm{MBP}}$ is recruited to PGC- $1 \alpha$ targeted promoters through the suppressor domain of this coactivator (Fig. 6). That $\mathrm{p} 160^{\mathrm{MBP}}$ has inherent transcriptional suppression activity is shown by the fact that this molecule can suppress transcription even when cova-
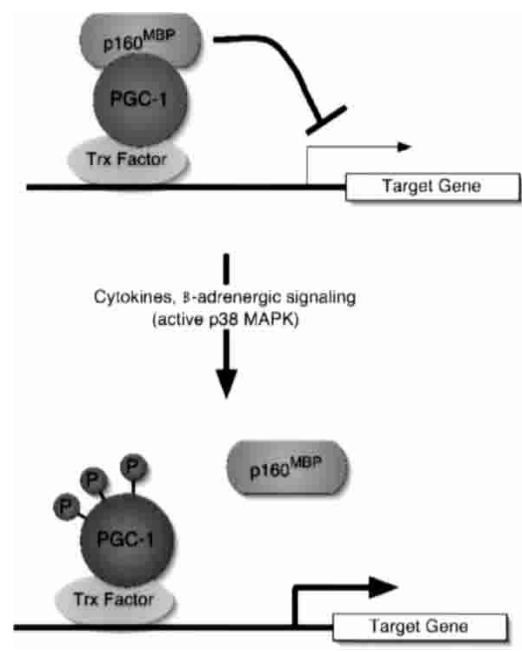

Figure 6. Schematic representation of $\mathrm{p} 160^{\mathrm{MBP}}$ repression of PGC-1 $\alpha$ on DNA; regulation by p38 MAPK signaling events. $\mathrm{p} 160^{\mathrm{MBP}}$ binds to PGC- $1 \alpha$ and represses transcription of PGC- $1 \alpha$ target genes. On cytokine or $\beta$-adrenergic signaling, p38 MAPK becomes active and phosphorylates PGC- $1 \alpha$. The phosphates disrupt $\mathrm{p} 160^{\mathrm{MBP}}$ binding to PGC-1 $\alpha$, leading to increased activation of PGC- $1 \alpha$ target genes. lently linked to the DNA-binding domain of Gal4. Addition of the histone deacetylase inhibitor trichostatin A partially reverses this repression, suggesting the involvement of histone deacetylase activity in $\mathrm{p} 160^{\mathrm{MBP}}$-mediated transcriptional repression.

The role of $\mathrm{p} 160^{\mathrm{MBP}}$ in controlling the stability of PGC-1 $\alpha$ is not completely clear at present. In some cell types, such as HIB1B, coexpression of $\mathrm{p} 160^{\mathrm{MBP}}$ reduces the amount of PGC-1 $1 \alpha$ protein, and this reduction is dependent on the $\mathrm{p} 160^{\mathrm{MBP}}$ binding domain of PGC- $1 \alpha$. On the other hand, we have not been able to show an effect on PGC- $1 \alpha$ protein stability in other cell types, such as C2C12 myotubes. These data suggest that $160^{\mathrm{MBP}}$ can control the amount of PGC-1 $\alpha$ protein, probably via stability, but that there may be additional molecules involved in this process. The purification of certain subunits of the anaphase promoting complex with the suppressor domain of PGC- $1 \alpha$ certainly suggests the possible involvement of the protein-destruction apparatus in this process.

The mechanisms illustrated here-namely, the p160 ${ }^{\mathrm{MBP}}$ docking on PGC- $1 \alpha$ in a p38 MAPK-regulatable fashion-has therapeutic implications. Particularly in muscle, PGC- $1 \alpha$ has been shown to stimulate glucose uptake as well as mitochondrial biogenesis and respiration, all associated with increased energy expenditure. In fact, recent work from two groups has shown a decrease in expression of PGC- $1 \alpha$ and its target genes in the muscle of type 2 diabetics and prediabetics, individuals with no disease, but with a high likelihood of developing diabetes (Mootha et al. 2003; Patti et al. 2003). These studies have suggested that even a mild to moderate increase in PGC-1 $\alpha$ function might benefit these patients. The data here suggest that inhibition of the docking of p $160^{\mathrm{MBP}}$ on PGC-1 $\alpha$ would increase the biological effects of this coactivator. Although inhibition of proteinprotein interactions by a small molecule might not be easy, the fact that this docking event is apparently structured so that it is disrupted by a limited number of phosphorylations indicates that the relevant protein surfaces controlling this binding may not be large. Such an inhibitor could prove useful in the treatment of type II diabetes.

\section{Materials and methods}

Preparation of GST fusion proteins and nuclear extracts

Bacterially produced GST-PGC1 $\alpha$ fusion proteins were generated by inducing BL2 1 cells containing GST-PGC1 $\alpha$ plasmids with $1 \mathrm{mM}$ IPTG for $3 \mathrm{~h}$. The cells were then sonicated and centrifuged to remove cell debris. The supernatant was incubated with glutathione-sepharose beads to purify the GST protein. The beads were then washed in PBS and stored at $4^{\circ} \mathrm{C}$. To generate phosphorylated GST-PGC1 $\alpha$, we carried out an in vitro phosphorylation reaction using activated p38 $\alpha$ MAPK (Upstate Biotechnology). Nuclear extracts were prepared from C2C12 myoblasts using the Dignam protocol (Dignam et al. 1983). Cells were incubated on ice with hypotonic Solution A $(10 \mathrm{mM}$ HEPES-KOH at $\mathrm{pH} 7.9,10 \mathrm{mM} \mathrm{KCl}, 1.5 \mathrm{mM} \mathrm{MgCl}_{2}, 0.5 \mathrm{mM}$ DTT, $0.5 \%$ NP-40, protease inhibitors) for $5 \mathrm{~min}$, then vortexed and spun at $1000 \mathrm{~g}$ for $5 \mathrm{~min}$ to pellet the nuclei. The nuclei were 
resuspended in Solution B (20 mM HEPES-KOH at $\mathrm{pH} 7.9,400$ $\mathrm{mM} \mathrm{NaCl}, 1.5 \mathrm{mM} \mathrm{MgCl}_{2}, 0.5 \mathrm{mM}$ DTT, $0.2 \mathrm{mM}$ EDTA, 15\% glycerol, protease inhibitors) and shaken, not stirred, at $4^{\circ} \mathrm{C}$ for $20 \mathrm{~min}$ to extract nuclear proteins. Samples were spun at $16,000 \mathrm{~g}$ for $10 \mathrm{~min}$ and supernatant was stored at $-80^{\circ} \mathrm{C}$.

\section{Affinity purification with $P G C-1 \alpha$ regulatory domain}

$\mathrm{C} 2 \mathrm{C} 12$ nuclear extracts were diluted in three volumes of dilution buffer (20 mM HEPES-KOH at $\mathrm{pH} 7.9,1.5 \mathrm{mM} \mathrm{MgCl}_{2}, 1$ mM DTT, 0.2 mM EDTA, 15\% glycerol, protease inhibitors) and precleared on glutathione sepharose beads for $1 \mathrm{~h}$ at $4^{\circ} \mathrm{C}$. The extract was then incubated with the GST-PGC1 $\alpha$ fusion proteins overnight at $4^{\circ} \mathrm{C}$. After washing in HEGN $(20 \mathrm{mM}$ HEPES at $\mathrm{pH} 7.6,0.15 \mathrm{M} \mathrm{KCl}, 0.1 \mathrm{mM}$ EDTA, $10 \%$ glycerol, $0.1 \%$ NP-40, $1 \mathrm{mM}$ DTT, protease inhibitors), the GST proteins were eluted with $20 \mathrm{mM}$ glutathione $(20 \mathrm{mM}$ glutathione, 20 mM HEPES at pH 7.6, 0.1 M KCl, $0.1 \mathrm{mM}$ EDTA, $10 \%$ glycerol, $0.025 \%$ NP-40, 1 mM DTT, protease inhibitors), TCA precipitated, and run on an SDS-PAGE gel. The gels were either subjected to silver staining or Western blotting as indicated.

\section{Protein identification by mass spectrometry}

Gel-resolved proteins were digested with trypsin, partially fractionated, and the resulting peptide mixtures analyzed by matrix-assisted laser-desorption/ionization reflectron time-offlight (MALDI-reTOF) MS (Reflex III; BRUKER Daltonics), as described (Erdjument-Bromage et al. 1998); and also using an electrospray ionization triple quadrupole MS/MS instrument (API300; ABI/MDS SCIEX) modified with an ultrafine ionization source (Geromanos et al. 2000). Selected precursor or fragment ion masses from the MALDI-TOF MS or NanoES-MS/MS spectra were taken to search a nonredundant protein database, as described (Winkler et al. 2002). MS/MS spectra also were inspected for $\mathrm{y}^{\prime \prime}$ ion series to compare with the computer-generated fragment ion series of the predicted tryptic peptides.

\section{GST purifications of ${ }^{35} \mathrm{~S}$ in vitro-translated proteins}

GST proteins were incubated with ${ }^{35} \mathrm{~S}$-labeled in vitro translated proteins (TnT kit, Promega) in binding buffer containing 100 mM HEPES (pH 7.7), 375 mM KCl, 0.5 mM EDTA, 12.5 mM $\mathrm{MgCl}_{2}, 0.25 \% \mathrm{NP}-40$, and $50 \%$ glycerol supplemented with $0.5 \%$ milk for $1 \mathrm{~h}$ at room temperature. The beads were washed three times in binding buffer without milk before being resuspended in SDS loading buffer and run on SDS-PAGE gels.

\section{Mammalian cell culture and transfections/infections}

C2C12, HIB1B, and BOSC cells were grown in Dulbecco's Modified Eagle's Medium supplemented with either $10 \%$ cosmic calf serum or $10 \%$ fetal bovine serum. For transcription assays, cells were transfected with luciferase reporter plasmids as well as Gal4 fusions or PPAR $\gamma$ and $\mathrm{p} 160^{\mathrm{MBP}}$ or $\mathrm{p} 67^{\mathrm{MBP}}$ as indicated. Trichostatin A (Sigma) was added to cells at $100 \mu \mathrm{g} / \mathrm{mL}$ for $12 \mathrm{~h}$ as indicated. After $1 \mathrm{~d}$, cells were lysed, tested for luciferase activity, and normalized to $\beta$-galactosidase activity for transfection efficiency. To visualize protein, we generated whole-cell extracts by incubating the cells in lysis buffer $(20$ mM HEPES$\mathrm{KOH}$ at $\mathrm{pH} 7.9,125 \mathrm{mM} \mathrm{NaCl}, 0.1 \% \mathrm{NP}-40,1$ mM EDTA, 1 $\mathrm{mM}$ DTT, protease inhibitors), freeze-thawing in liquid nitrogen, and centrifuging to remove the debris. Immunoprecipitations were carried out in $\mathrm{M} 2$ lysis buffer $(50 \mathrm{mM}$ Tris- $\mathrm{HCl}$ at $\mathrm{pH}$ 7.8, $137 \mathrm{mM} \mathrm{NaCl}, 10 \mathrm{mM} \mathrm{NaF}, 1 \mathrm{mM}$ EDTA, $1 \%$ Triton-X100, $0.2 \%$ sarkosyl, $1 \mathrm{mM} \mathrm{DTT}, 10 \%$ glycerol, fresh proteinase, phosphatase inhibitors) for $4 \mathrm{~h}$ and washed three times in M2 lysis buffer. For Northern blots, cells were harvested in Trizol reagent (Invitrogen) for subsequent RNA purification. For cytokine treatment, $\mathrm{C} 2 \mathrm{C} 12$ cells were incubated in culture medium containing $0.5 \%$ BSA in place of serum. Human TNF $\alpha$ (10 ng/ $\mathrm{mL})$ and human IL- $1 \alpha$ and IL- $1 \beta(2 \mathrm{ng} / \mathrm{mL})$ were added as indicated for $12 \mathrm{~h}$ for coimmunoprecipitations and $24 \mathrm{~h}$ for target gene experiments. For adenoviral experiments, adenoviruses were generated in 293 cells and infection rates were monitored using GFP fluorescence.

\section{Oxygen consumption assays}

Oxygen consumption measurements were carried out as described previously (Wu et al. 1999; St-Pierre et al. 2003). Basically, cells were isolated by washing with PBS and trypsinizing for 5 min. DMEM with 10\% FBS was added to step the reaction and the cells were resuspended and spun twice at $1000 \mathrm{rpm}$ for 5 min. Finally, cells were resuspended in DPBS supplemented with $25 \mathrm{mM}$ glucose, $1 \mathrm{mM}$ pyruvate, and $2 \%$ BSA.

\section{Plasmids}

$\mathrm{p} 160^{\mathrm{MBP}}$ and its deletion constructs were cloned into the mammalian expression vector pcDNA3.1-Myc-His (Invitrogen) between EcoRV and HindIII. Nuclear localization signals were added to $\mathrm{p} 160^{\mathrm{MBP}}$ deletions 1-200, 200-400, and 400-580. Gal4p160/p67 constructs were cloned into pCMX between EcoRI and EcoRV. Point mutants were generated using the Quikchange site-directed mutagenesis kit (Stratagene). Adenop160/p67 constructs were cloned into pAdTrack-CMV between EcoRV and HindIII before being recombined into pAdEasy.

\section{Chromatin immunoprecipitation assay}

C2C12 myotubes were infected with adenoviral MEF2C, Flagtagged PGC1 $\alpha$, and $\mathrm{p} 160^{\mathrm{MBP}}$. Cells were harvested after $2 \mathrm{~d}$ and chromatin immunoprecipitation was conducted by using the Upstate Biotechnology Kit (Cat\#17-295) with M2 anti-Flag antibodies. Input DNA and immunoprecipitated DNA were subjected to PCR analysis with the primers $5^{\prime}$-AAGTCCAGACA GTGACCTGGCTG $-3^{\prime}$ and 5 '-TGGGTGCCACATGCCCTTC CTGC-3', which flank the MEF2C site at nucleotide -130 on the myoglobin promoter (Yan et al. 2001), and the primers $5^{\prime}$ GTCGTGGAGTCTACTGGTGTC-3' and 5'-CTAAGCAGTT GGTGGTGCAGG-3', which flank a region of the GAPDH gene.

\section{Acknowledgments}

We thank Dr. Tom Gonda, Dr. Phil Hieter, Dr. Anthony Hollenberg, Dr. Sanders Williams, Dr. Jeff Parvin, Dr. Guillaume Adelmant, Dr. Zhidan Wu, and Bryan Sun for reagents. We thank Dr. Christoph Rachez, Stuart Levine, Dr. Stefanie Hauser, and members of the Spiegelman Lab, especially Paul Tarr, Dr. Geoffrey Girnun, Dr. Wenli Yang, and Lindsay Rohas, for thoughtful discussion and technical assistance. This work was supported by NIH grant DK54477 (to B.M.S.) and NCI Cancer Center Support Grant P30 CA08748 (to P.T.). M.F. was supported by NIH Training Grant 5T32EY07110.

The publication costs of this article were defrayed in part by payment of page charges. This article must therefore be hereby marked "advertisement" in accordance with 18 USC section 1734 solely to indicate this fact. 


\section{References}

Cao, W., Medvedev, A.V., Daniel, K.W., and Collins, S. 2001. beta-Adrenergic activation of $\mathrm{p} 38$ MAP kinase in adipocytes: cAMP induction of the uncoupling protein 1 (UCP1) gene requires p38 MAP kinase. J. Biol. Chem. 276: 27077-27082.

Dignam, J.D., Lebovitz, R.M., and Roeder, R.G. 1983. Accurate transcription initiation by RNA polymerase II in a soluble extract from isolated mammalian nuclei. Nucleic Acid Res. 11: $1475-1489$.

Erdjument-Bromage, H., Lui, M., Lacomis, L., Grewal, A., Annan, R.S., McNulty, D.E., Carr, S.A., and Tempst, P. 1998. Examination of micro-tip reversed-phase liquid chromatographic extraction of peptide pools for mass spectrometric analysis. J. Chromatogr. A 826: 167-181.

Geromanos, S., Freckleton, G., and Tempst, P. 2000. Tuning of an electrospray ionization source for maximum peptide-ion transmission into a mass spectrometer. Anal. Chem. 72: 777-790.

Handschin, C., Rhee, J., Lin, J., Tarr, P.T., and Spiegelman, B.M. 2003. An autoregulatory loop controls peroxisome proliferator-activated receptor gamma coactivator 1alpha expression in muscle. Proc. Natl. Acad. Sci. 100: 7111-7116.

Herzig, S., Long, F., Jhala, U.S., Hedrick, S., Quinn, R., Bauer, A., Rudolph, D., Schutz, G., Yoon, C., Puigserver, P., et al. 2001. CREB regulates hepatic gluconeogenesis through the coactivator PGC-1. Nature 413: 179-183.

Ichida, M., Nemoto, S., and Finkel, T. 2002. Identification of a specific molecular repressor of the peroxisome proliferatoractivated receptor gamma Coactivator-1 alpha (PGC-1alpha). J. Biol. Chem. 277: 50991-50995.

Jones, L.C., Okino, S.T., Gonda, T.J., and Whitlock Jr., J.P. 2002. Myb-binding protein la augments AhR-dependent gene expression. J. Biol. Chem. 277: 22515-22519.

Knutti, D., Kressler, D., and Kralli, A. 2001. Regulation of the transcriptional coactivator PGC-1 via MAPK-sensitive interaction with a repressor. Proc. Natl. Acad. Sci. 98: 9713-9718.

Lehman, J.J., Barger, P.M., Kovacs, A., Saffitz, J.E., Medeiros, D.M., and Kelly, D.P. 2000. Peroxisome proliferator-activated receptor gamma coactivator-1 promotes cardiac mitochondrial biogenesis. J. Clin. Invest. 106: 847-856.

Lin, J., Wu, H., Tarr, P.T., Zhang, C.Y., Wu, Z., Boss, O., Michael, L.F., Puigserver, P., Isotani, E., Olson, E.N., et al. 2002. Transcriptional co-activator PGC-1 alpha drives the formation of slow-twitch muscle fibres. Nature 418: 797-801.

Luo, Y. and Roeder, R.G. 1995. Cloning, functional characterization, and mechanism of action of the B-cell-specific transcriptional coactivator OCA-B. Mol. Cell. Biol. 15: 41154124.

Michael, L.F., Wu, Z., Cheatham, R.B., Puigserver, P., Adelmant, G., Lehman, J.J., Kelly, D.P., and Spiegelman, B.M. 2001. Restoration of insulin-sensitive glucose transporter (GLUT4) gene expression in muscle cells by the transcriptional coactivator PGC-1. Proc. Natl. Acad. Sci. 98: 38203825.

Mootha, V.K., Lindgren, C.M., Eriksson, K.F., Subramanian, A., Sihag, S., Lehar, J., Puigserver, P., Carlsson, E., Ridderstrale, M., Laurila, E., et al. 2003. PGC-1alpha-responsive genes involved in oxidative phosphorylation are coordinately downregulated in human diabetes. Nat. Genet. 34: 267-273.

Patti, M.E., Butte, A.J., Crunkhorn, S., Cusi, K., Berria, R., Kashyap, S., Miyazaki, Y., Kohane, I., Costello, M., Saccone, R., et al. 2003. Coordinated reduction of genes of oxidative metabolism in humans with insulin resistance and diabetes: Potential role of PGC1 and NRF1. Proc. Natl. Acad. Sci. 100: 8466-8471.
Puigserver, P. and Spiegelman, B.M. 2003. Peroxisome proliferator-activated receptor-gamma coactivator 1alpha (PGC-1alpha): Transcriptional coactivator and metabolic regulator. Endocr. Rev. 24: 78-90.

Puigserver, P., Wu, Z., Park, C.W., Graves, R., Wright, M., and Spiegelman, B.M. 1998. A cold-inducible coactivator of nuclear receptors linked to adaptive thermogenesis. Cell 92: 829-839.

Puigserver, P., Adelmant, G., Wu, Z., Fan, M., Xu, J., O'Malley, B., and Spiegelman, B.M. 1999. Activation of PPARgamma coactivator-1 through transcription factor docking. Science 286: $1368-1371$.

Puigserver, P., Rhee, J., Lin, J., Wu, Z., Yoon, J.C., Zhang, C.Y., Krauss, S., Mootha, V.K., Lowell, B.B., and Spiegelman, B.M. 2001. Cytokine stimulation of energy expenditure through p38 MAP kinase activation of PPARgamma coactivator-1. Mol. Cell 8: 971-982.

Puigserver, P., Rhee, J., Donovan, J., Walkey, C.J., Yoon, J.C., Oriente, F., Kitamura, Y., Altomonte, J., Dong, H., Accili, D., et al. 2003. Insulin-regulated hepatic gluconeogenesis through FOXO1-PGC-1alpha interaction. Nature 423: 550-555.

Rhee, J., Inoue, Y., Yoon, J.C., Puigserver, P., Fan, M., Gonzalez, F.J., and Spiegelman, B.M. 2003. Regulation of hepatic fasting response by PPARgamma coactivator-1alpha (PGC-1): Requirement for hepatocyte nuclear factor 4alpha in gluconeogenesis. Proc. Nat1. Acad. Sci. 100: 4012-4017.

St-Pierre, J., Lin, J., Krauss, S., Tarr, P.T., Yang, R., Newgard, C.B., and Spiegelman, B.M. 2003. Bioenergetic analysis of PGC-1alpha and PGC-1beta in muscle cells. J. Biol. Chem. 278: 26597-26603.

Tavner, F.J., Simpson, R., Tashiro, S., Favier, D., Jenkins, N.A., Gilbert, D.J., Copeland, N.G., Macmillan, E.M., Lutwyche, J., Keough, R.A., et al. 1998. Molecular cloning reveals that the p160 Myb-binding protein is a novel, predominantly nucleolar protein which may play a role in transactivation by Myb. Mol. Cell. Biol. 18: 989-1002.

Tiraby, C., Tavernier, G., Lefort, C., Larrouy, D., Bouillaud, F., Ricquier, D., and Langin, D. 2003. Acquirement of brown fat cell features by human white adipocytes. J. Biol. Chem. 278: 33370-33376.

Tracey, K.J., Fong, Y., Hesse, D.G., Manogue, K.R., Lee, A.T., Kuo, G.C., Lowry, S.F., and Cerami, A. 1987. Anti-cachectin/TNF monoclonal antibodies prevent septic shock during lethal bacteraemia. Nature 330: 662-664.

Vega, R.B., Huss, J.M., and Kelly, D.P. 2000. The coactivator PGC-1 cooperates with peroxisome proliferator-activated receptor alpha in transcriptional control of nuclear genes encoding mitochondrial fatty acid oxidation enzymes. Mol. Cell. Biol. 20: 1868-1876.

Winkler, G.S., Lacomis, L., Philip, J., Erdjument-Bromage, H., Svejstrup, J.Q., and Tempst, P. 2002. Isolation and mass spectrometry of transcription factor complexes. Methods 26: 260-269.

Wu, Z., Puigserver, P., Andersson, U., Zhang, C., Adelmant, G., Mootha, V., Troy, A., Cinti, S., Lowell, B., Scarpulla, R.C., et al. 1999. Mechanisms controlling mitochondrial biogenesis and respiration through the thermogenic coactivator PGC-1. Cell 98: 115-124.

Yan, Z., Serrano, A.L., Schiaffino, S., Bassel-Duby, R., and Williams, R.S. 2001. Regulatory elements governing transcription in specialized myofiber subtypes. J. Biol. Chem. 276: 1736117366.

Yoon, J.C., Puigserver, P., Chen, G., Donovan, J., Wu, Z., Rhee, J., Adelmant, G., Stafford, J., Kahn, C.R., Granner, D.K., et al. 2001. Control of hepatic gluconeogenesis through the transcriptional coactivator PGC-1. Nature 413: 131-138. 


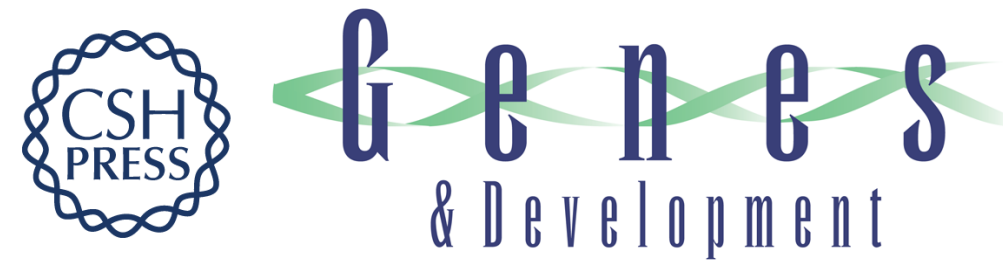

\section{Suppression of mitochondrial respiration through recruitment of p160 myb binding protein to PGC-1 $\alpha$ : modulation by p38 MAPK}

Melina Fan, James Rhee, Julie St-Pierre, et al.

Genes Dev. 2004, 18:

Access the most recent version at doi:10.1101/gad.1152204

Supplemental http://genesdev.cshlp.org/content/suppl/2004/01/26/1152204.DC1
Material

References This article cites 30 articles, 15 of which can be accessed free at:

http://genesdev.cshlp.org/content/18/3/278.full.html\#ref-list-1

License

Email Alerting Receive free email alerts when new articles cite this article - sign up in the box at the top

Service

right corner of the article or click here.

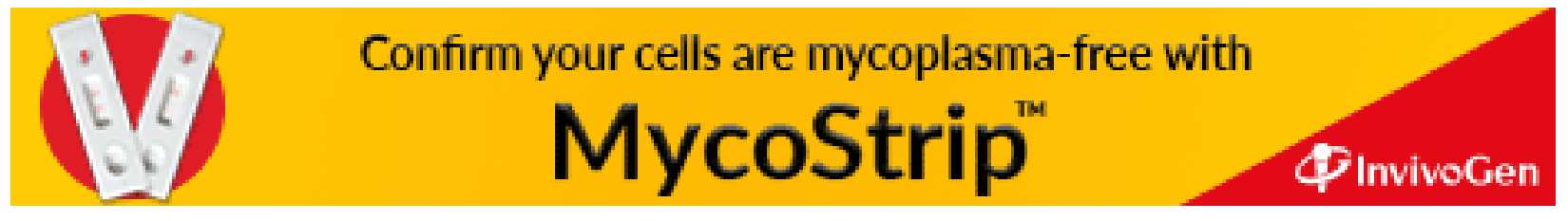

